\title{
Isolated thoracic duct injury from blunt force trauma
}

\author{
Shelby Champion ${ }^{1 *}$, Victor Lam Shin Cheung ${ }^{2}$, Daniele Wiseman ${ }^{3}$ \\ 1. Schulich School of Medicine and Dentistry, Western University, London, Ontario, Canada \\ 2. Western Radiology, London Health Science Centre, London, Ontario, Canada \\ 3. Department of Medical Imaging, London Health Science Centre, London, Ontario, Canada \\ * Correspondence: Shelby Champion BSc, Schulich School of Medicine and Dentistry, Western University, 1209 Richmond St., London, \\ Ontario, N6A 3L7, Canada \\ (《) schampio@uwo.ca)
}

Radiology Case. 2020 Sep; 14(9):18-29 :: DOI: $10.3941 /$ jrcr.v14i9.3977

\begin{abstract}
Isolated thoracic duct injury is an uncommon clinical event and is rare in the setting of trauma. We describe a case of an isolated thoracic duct injury resulting in the development of bilateral chylothorax following a motor vehicle collision in the absence of any other definable injury. We outline the initial patient presentation and diagnosis. After failing a trial of conservative management the patient underwent lymphangiography followed by thoracic duct ligation with pleurodesis. This case highlights the importance of recognizing thoracic duct injury following trauma.
\end{abstract}

\section{CASE REPORT}

\section{CASE REPORT}

A 29-year-old male was brought to the Emergency Department following a motor vehicle collision whereby his vehicle was rear ended. Cervical spine radiographs were normal. Initial chest radiograph revealed small bilateral pleural effusions (Figure 1). The patient was discharged home as he was asymptomatic and did not warrant hospital admission. The next day the patient presented to hospital following an episode of difficulty breathing accompanied by flushing, diaphoresis, and vomiting. Repeat chest X-ray identified increasing bilateral large pleural effusions (Figure 2). A follow up Computed Tomography (CT) scan of the abdomen and thorax confirmed large bilateral pleural effusions (Figure 3). There were no fractures and no intraabdominal injuries. On physical examination, the patient was hemodynamically stable with no signs of significant respiratory distress. There was mild tenderness of the right anterior thorax and decreased bilateral air entry to the base of the lungs.
A chest tube was inserted in the right mid-axillary line; from which, $1500 \mathrm{~mL}$ of white to strawberry-coloured fluid was drained with no evidence of blood. The effusion sample was found to have a triglyceride level of $42.26 \mathrm{mmol} / \mathrm{L}$ and cholesterol of $2.86 \mathrm{mmol} / \mathrm{L}$ indicating the presence of chyle. A left chest tube was also placed for a large chylothorax.

Initially, the patient was treated conservatively for his chylothorax with octreotide, total parenteral nutrition and chest tube drainage. With little improvement in the chylothorax after 5 days, an intranodal ultrasound (US) guided lymphangiogram was performed. Lipiodol $(30 \mathrm{~mL}$ total) was injected slowly into the left and right inguinal lymph nodes accessed with a 22-gauge needle under direct ultrasonic guidance. Intermittent fluoroscopy showed bilateral uptake into the lymphatic chain (Figure 4a). Over time, an amorphic area of Lipiodol began to accumulate over the 10th thoracic vertebra (Figure 4b). Increased attenuation to the left of the midline between the 11th-12th left ribs was suspected to be pooling of the Lipiodol in the left pleural space. A follow up non-contrast $\mathrm{CT}$ of the thorax confirmed an amorphic 
collection of lipiodol spilling directly from the well opacified thoracic duct at the 10th thoracic vertebra with relative diminished caliber of the thoracic duct thereafter, in keeping with disruption of the thoracic duct (Figure 5).

After 9 days of non-operative treatment with no resolution of the patient's chylothorax, surgical management was offered. An open surgical approach was undertaken with a right sided posterolateral thoracotomy. The thoracic duct was ligated at the level of the identified thoracic duct leak. Pleurodesis was performed using a talc mixture to prevent reaccumulation of chyle within the pleural space. Bilateral chest tubes and a left sided pigtail pleural catheter were left in place. Following the procedure, a portable chest radiograph revealed small bilateral effusions (Figure 6). The patient was slowly transitioned back to an oral diet and the chest tubes were removed. A chest X-ray performed 6 weeks post-surgery demonstrated resolving chylothorax (Figure 7).

\section{DISCUSSION}

\section{Etiology \& Demographics:}

Blunt force trauma is a rare cause of thoracic duct injury, particularly in the absence of any other associated injuries. Approximately $50 \%$ of thoracic duct injuries are the result of a traumatic injury [1]. Of those traumatic injuries $80 \%$ are iatrogenic [2]. The other $20 \%$ are caused by penetrating or blunt trauma. Although rare, isolated thoracic duct injuries have also been reported with hyperextension of the spine or forceful cough and emesis [3-7].

The thoracic duct is created by the joining of lymphatic vessels from the lower limbs at the point of the cisterna chyli within the retroperitoneum located at roughly the second lumbar vertebra. The duct ascends between the aorta and the azygos vein, anterior to the vertebral column. Caudally, the thoracic duct runs to the right of the aorta in the aortoesophageal recesses. However, at the level of the fourth to sixth thoracic vertebrae the thoracic duct crosses over the midline to travel posterior to the esophagus. This anatomy is present in $\sim 50 \%$ of the population [8]. In keeping with the common anatomy, injury below the level of the fifth thoracic vertebra often leads to a right sided chylothorax, while injury above the fifth thoracic vertebra is associated with effusion on the left [9]. Damage below the diaphragm results in chylous ascites.

Given the location of the thoracic duct within the body it is seldom injured in isolation. It is understandable how an isolated thoracic duct injury can occur following penetrating trauma and there are numerous cases reported in the literature describing this event [10-12]. Many cases of thoracic duct injury following blunt force trauma do not happen in isolation, often these cases also involve fractures within the thorax [1321]. These fractures may be associated with direct trauma to the thoracic duct leading to a tear in the lymphatics. Damage to the thoracic duct in which there are no other injuries present are quite rare. To our knowledge there have only been 9 cases of chylothorax resulting from an isolated thoracic duct injury following blunt trauma reported in the literature since 1990
[19,22-28] with 13 cases of isolated chyloperitoneum or chyloretroperitoneum [29-41].

In general, chylothorax is a relatively uncommon clinical event. It is most often associated with malignancy or postoperative complication of thoracic surgery. A retrospective case review performed by Doerr et al. (2005) examined 203 patients at the Mayo Clinic that developed a chylothorax over a period of 21 years. Almost half of the reported cases at their institution were the result of surgery or trauma. The vast majority within this group were iatrogenic in nature with the highest rates being due to esophagectomy, cardiovascular surgery or mass resection in the mediastinum [1]. Despite the most common cause of chylothorax being due to surgical complications, it is only seen in roughly $0.4 \%$ of surgical procedures in the thorax [42]. Outside of surgical trauma and malignancy, chylothorax is exceedingly rare. Valentine and Raffin found that only $3 \%$ of cases of chylothorax were due to non-surgical trauma after reviewing 191 cases from 1964-1986 [43]. Doerr et al. (2005) found only a single case of chylothorax due to blunt force trauma out of the 203 cases studied [1].

There are case reports of spontaneous chylothorax in which there is no apparent trauma. It is postulated that these spontaneous events have the same etiology as blunt trauma in which the thoracic duct is damaged through increased intrathoracic pressure and/or hyperextension of the spine [37]. In 1952, Meade studied 5 such cases of spontaneous chylothorax in which no direct cause could be identified. Upon further review, it was noted that 4 out of the 5 patients experienced sudden hyperextension of the spine prior to the development of chylothorax. Reviewing the patient histories, all 5 patients had evidence of fixation of the thoracic duct to the vertebrae through prior trauma, infection or congenital anomaly [7].

One of the first reviews in the literature regarding traumatic chylothorax was done by McNab and Scarlett in 1932. They reported 34 cases of traumatic chylothorax with 28 cases being due to blunt trauma. Of the 28 , there were 19 cases of isolated thoracic duct injury, with no external wounds or fracture to the ribs or vertebrae. Most injuries were the result of automobile accidents or falls from moderate heights [44]. This early report formed a large base of our knowledge regarding traumatic thoracic duct injury. However, it does not appear to reflect the cases reported in the current literature. Perhaps this is due to increased force of impact in modern automobile accidents resulting in more severe trauma than an isolated thoracic duct injury. Additionally, in the early 1900s there was a decreased ability to detect underlying medical conditions and/or malignancies that could have made the thoracic duct more prone to rupture. Due to these limitations there is potential that some of the cases of isolated thoracic duct injury presented by McNab and Scarlett (1932) were truly due to underlying medical conditions and may have been misattributed to blunt trauma.

\section{Clinical \& Imaging findings:}

Chylothorax is difficult to differentiate from other causes of pleural effusion on most imaging modalities. On US a chylothorax will appear as a homogeneous region of 
echogenicity [45]. There should not be any areas of loculation or sepatation [45]. On chest X-ray a pleural effusion is characterized by blunting of the costophrenic and cardiophrenic angles. For a chylothorax the area of effusion will appear homogeneous [45]. The use of CT may provide a degree of differentiation of the underlying etiology of the pleural effusion, although its utility is limited. A chylous effusion will have a lower attenuation value than other forms of pleural effusion [45]. Conclusive diagnosis requires a laboratory analysis of the pleural fluid with triglyceride level $>1.24 \mathrm{mmol} / \mathrm{L}$ with a cholesterol level $<5.18 \mathrm{mmol} / \mathrm{L}$ [1]. Once the diagnosis of chylothorax has been reached, lymphangiography is the gold standard to determine the precise location of the thoracic duct injury. The American College of Radiology recommends only using CT and Magnetic Resonance Imaging (MRI) when the precise anatomic details required for surgical planning are not obtained from lymphangiography [46]. Proper visualization of the site of injury within the thoracic duct using MRI requires gadolinium contrast injected in a similar fashion to lymphangiography [47]. Lymphangiography remains invaluable to identify anatomic details.

\section{Treatment \& Prognosis:}

If lymphatic leakage goes unnoticed serious complications can develop. Large losses of chyle can lead to hypovolemia if the fluid volume is not adequately replaced [48]. Chyle is dense in nutrients and lymphatic cells and continuous loss of these biologically important molecules and cells can lead to malnutrition and immunosuppression [48]. There is typically a delay between the time of injury and the presentation of a chylothorax to medical attention. The delay is due to the time it takes for the chyle to leak into the mediastinum and the pressure to be large enough to enter the pleural space. Typically, this delay can be from 2-7 days $[44,48]$. Approximately $57 \%$ of patients initially present with dyspnea, however $37 \%$ of patients may experience no symptoms at the time of diagnosis [1]. If untreated the mortality rate for traumatic chylothorax is $50 \%$ [44]. The delayed presentation and potentially insidious onset of a chylothorax can cause difficulty in diagnosis, especially for a rare etiology. Therefore, it is important to recognize potential chylothorax following blunt force trauma.

There are currently no treatment guidelines for the management of lymphatic duct injury. Generally, a trial of conservative management is taken before offering definitive surgical treatment. The utility of conservative management is variable, with the literature quoting success rates between 20 $80 \%$ [2]. There is currently no defined length of time that conservative management of chylothorax should be trialed, although consensus is not to go beyond 2 weeks [49].

Conservative management typically includes thoracentesis and nil per os (NPO) status while the patient is maintained with total parenteral nutrition. The administered nutrition should be low in fat to minimize the body's production of chyle. Thoracentesis is done for symptom management of the developing chylothorax. NPO status is required to reduce the volume of chyle that is lost and allow the thoracic duct injury to heal [17]. Octreotide can be given as it can slow the production of chyle [2].
If a trial of conservative therapy is unsuccessful, lymphangiography may provide both therapeutic and diagnostic benefit. A contrast agent, typically lipiodol, is injected into the lymphatic system by either pedal or inguinal nodes under US guidance. Targeting of the inguinal nodes has become common practice as the transit time to the site of leak is reduced, therefore reducing time, volume of lipiodol used and radiation dose. Serial fluoroscopic images are then obtained approximately every 5-10 minutes to track uptake into the thoracic duct. Traditionally, lymphangiography was performed prior to surgery to identify the site of leak and aid in surgical planning. However, recent data has shown that lymphangiography alone is enough to correct thoracic duct injuries in 50-90\% of instances [50-53]. With the recent introduction of US guided intranodal lymphangiography at our institution, as performed by the senior author, the local rate of therapeutic benefit is currently at $50 \%$. The exact mechanism in treating chyle leakage is unknown. Matsmuto et al. (2009) hypothesizes that lipiodol accumulation causes an inflammatory reaction that leads to therapeutic embolization [50]. Lymphangiography carries with it the standard risks of bleeding, infection, and pain. In rare cases serious complications such as lipiodol related pulmonary embolisms or anaphylaxis can occur [54].

If the chylous leak persists following the lymphangiogram, treatment can be escalated to more definitive options such as thoracic duct embolization or thoracic duct ligation. Thoracic duct embolization (TDE) is an interventional technique done immediately after lymphangiography. The cisterna chyli is targeted through percutaneous transabdominal catheterization while the thoracic duct and site of injury are visible due to the injected contrast. The catheter is advanced to the point of the leakage under fluoroscopic guidance. Metallic coils and/or adhesive substances are then deployed to cause embolization at the site of injury. If the embolization procedure is completed it has a $90 \%$ rate of success [55]. Unfortunately, TDE is only successfully completed in approximately $67 \%$ of cases cannulated [55]. If TDE is unsuccessful a technique known as thoracic duct disruption can be used in which a needle is repeatedly passed through the duct in an effort to interrupt the lymphatic vessel and prevent further leakage. TDE carries a risk of developing protein-losing enteropathy, lymphedema, and chylous ascites [56]. Alternatively, thoracic duct ligation (TDL) is the act of repairing the point of thoracic duct leakage with sutures. This may be performed by thoracotomy or more commonly using video assistance. A high degree of surgical accuracy is required as the thoracic duct travels alongside critical blood vessels as well as the esophagus. To reduce the risk of perforation of the esophagus an orogastric tube is often used, which can be filled with methylene blue stained creams to improve recognition [57]. Overall, TDL is a relatively safe procedure with a high overall success rate of $90 \%$ [2]. The major postoperative complication is lymphedema, however over time symptoms usually decrease as collateral lymphatics develop [45]. Pleurodesis is a technique to cause scarring within the pleural space to prevent reaccumulation of fluid. This can be done alone or in conjunction with thoracic duct ligation. 


\section{Differential Diagnosis:}

Radiographs and CT are the mainstay of detection for the presence of pleural effusion. US can play a role in narrowing down differential diagnoses in settings with limited resources or increasing utilization of point of care US. Despite the importance of imaging, to reach a conclusive diagnosis of the underlying etiology, a sample of the pleural fluid must be drawn for laboratory analysis.

Transudative effusions occur in the context of systemic processes causing an imbalance in the starling forces. Therefore, on imaging they often present bilaterally in the basal portion of the lungs. These pleural effusions will have a homogenous, fluid-like appearance. MRI has limited use in delineating the etiology of a pleural effusion aside from distinguishing transudative from exudative effusions. On diffusion weighted MRI transudative effusions will appear isointense while exudative effusions are hyperintense [58]. The Light's Criteria is used to define a transudative effusion: a) pleural fluid/serum protein ratio $<0.5$, b) pleural fluid $\mathrm{LDH} /$ serum LDH $<0.6$, or c) pleural $\mathrm{LDH}<2 / 3$ the upper limit of normal serum LDH [59].

Pleural effusions may be seen alongside pneumonia. The pleural space can be filled with simple fluid or pus. These parapneumonic pleural effusions or empyemas occur in approximately $2-3 \%$ of all cases of pneumonia [60]. The presence of typical symptoms or radiologic evidence of pneumonia may help direct your differential diagnosis. For a simple parapneumonic effusion, the pleural fluid will collect in the dependent areas of the lungs. US examination may show evidence of consolidation. If an empyema develops adhesions may be visible on chest radiographs as areas of loculation with tapered borders. On contrast enhanced CT there will be a high degree of enhancement of both the visceral and parietal pleura creating the split pleura sign [61] . Pleural thickening may also be present [62]. In an empyema the retrieved sample of pleural fluid will contain pus with a positive bacterial culture.

Tuberculosis (TB) related effusions may be visible on US as complex septated effusions [63]. TB typically presents on $\mathrm{X}$-ray and CT as areas of focal infiltration in either the upper or lower lobes [64]. Approximately $24 \%$ of patients with TB will develop a pleural effusion [65]. Other signs of TB such as cavitation, consolidation, inflammation, as well as enlarged hilar and mediastinal lymph nodes may be present [64]. However, unilateral pleural effusion may be the sole manifestation [63]. The heightened resolution of contrast enhanced CT may reveal rim enhancing collections, loculations and septations in the case of pleural TB [66]. The diagnosis requires inoculation of Mycobacterium tuberculosis and a positive acid-fast bacilli stain from a sample of bodily fluid.

Primary pleural malignancy, hematological malignancy, or metastases to the pleura may lead to the development of pleural effusion. US may reveal heterogeneous echogenicity within the pleural fluid, thereby delineating the entity from a simple effusion. Indicators such as pulmonary masses or nodules, atelectasis from bronchial obstruction, or lymphadenopathy may be seen on radiographs. On CT pleural irregularities, nodules, or thickening of the pleura may be noted. In order to conclusively diagnose a malignant pleural effusion positive cytology on laboratory analysis must be obtained.

In the case of hemothorax, US has little utility beyond the detection of pleural effusion. Blood in the pleural space will appear as a homogeneous density, with little characterization of the fluid or the source. Large hemothoraces greater than $500 \mathrm{~mL}$ can be detected on upright chest X-ray [67]. To detect hemothoraces less than $500 \mathrm{~mL}, \mathrm{CT}$ imaging is required [68]. On CT fresh blood will have an elevated attenuation of greater than 35 Hounsfield Unit (HU), while clotted blood can have a HU of approximately 70 [69]. Hemothorax can be conclusively identified if the ratio of pleural fluid/blood hematocrit is found to be $\geq 0.5$ [70]. However, pleural fluid/blood hematocrit in the range of 0.25-0.5 may be related to a hemothorax that has undergone some form of secondary dilution [70].

\section{Conclusion:}

Isolated thoracic duct injury is a rare outcome of blunt force trauma. Presentation is often delayed until the development of a symptomatic chylothorax. Thoracic duct injury and subsequent chylothorax should be considered in patients experiencing late onset dyspnea following a traumatic injury. Conservative management can be trialed. Lymphangiography is a useful tool to aid in the diagnosis, localization, and management of thoracic duct injury. However, definitive surgical management should be offered if the chylothorax fails to resolve within a reasonable period of time.

\section{TEACHING POINT}

Isolated thoracic duct injury resulting in chylothorax due to blunt trauma is exceptionally rare and may be difficult to detect due to the delayed and insidious presentation. Once the presence of a chylothorax is detected, lymphangiography can be useful for localization and surgical planning, it may also treat the thoracic duct leak in approximately $50-90 \%$ of cases.

\section{REFERENCES}

1. Doerr CH, Allen MS, Nichols III FC, Ryu JH. Etiology of chylothorax in 203 patients. Mayo Clinic Proceedings. 2005 Jul; 80(7), 867-870. PMID: 16007891.

2. Pillay TG, Singh B. A review of traumatic chylothorax. Injury. 2016 Mar; 47(3), 545-550. PMID: 26776461.

3. Cammarata S K, Brush Jr R E, Hyzy R C. Chylothorax after childbirth. Chest. 1991 Jun; 99(6), 1539-1540. PMID: 2036852

4. Herzog KA, Branscom JJ. Spontaneous chylothorax. Chest. 1974 Mar; 65(3), 346-347. PMID: 4813841. 
5. Reilly KM, Tsou E. Bilateral chylothorax: a case report following episodes of stretching. JAMA. 1975 Aug; 233(6), 536-537. PMID: 1173668.

6. Sundberg RH. Chylothorax. California medicine. Feb 1948; 68(2), 99. PMID: 18731389.

7. Meade RH. Spontaneous Chylothorax: Observations on Its Pathogenesis and Management Based on Study of Five Cases. AMA archives of internal medicine. 1952 Jul; 90(1), 30-36. PMID: 14932534.

8. Ilahi M, Ilahi TB. Anatomy, Thorax, Thoracic Duct. StatPearls. Online Dec 2018. Available at: https://www.ncbi.nlm.nih.gov/books/NBK513227/. Accessed on May 20, 2020.

9. Bessone LN, Ferguson TB, Burford TH. Chylothorax. The Annals of thoracic surgery. 1971 Nov; 12(5), 527-550. PMID: 4942619.

10. Worthington MG, de Groot M, Gunning AJ, von Oppell UO. Isolated thoracic duct injury after penetrating chest trauma. The Annals of thoracic surgery. 1995 Aug; 60(2), 272-274. PMID: 7646086.

11. Shah PP, Deshmukh S, Tulshibagwala RK. Chylothorax: a case report. International Journal of Pharmacology Clinical Sciences. 2012 Dec; 1(4), 115-7. ISSN: 2278-0068.

12. Carrillo-Esper R, Sosa-García JO, Carrillo-Córdova CA. Chylothorax secondary to gunshot wound. Cir Cir. 2009 Dec; 77, 447-449. PMID: 20433790.

13. Sendama W, Shipley M. Traumatic chylothorax: A case report and review. Respiratory medicine case reports. 2015 Jan;14, 47-48. PMID: 26029578.

14. Townshend AP, Speake W, Brooks A. Chylothorax. Emergency Medicine Journal. 2007 Feb; 24(2), e11-e11. PMID: 17251600.

15. Idris K, Sebastian M, Hefny AF, Khan NH, Abu-Zidan FM. Blunt traumatic tension chylothorax: Case report and mini-review of the literature. World journal of clinical cases. 2016 Nov; 4(11), 380. PMID: 27900328.

16. Golden P. Chylothorax in blunt trauma: a case report. American Journal of Critical Care. 1999 May; 8(3), 189. PMID: 10228660.

17. McCormick III J, Henderson SO. Blunt trauma-induced bilateral chylothorax. The American journal of emergency medicine. 1999 May; 17(3), 302-304. PMID: 10337895.

18. Silen ML, Weber TR. Management of thoracic duct injury associated with fracture-dislocation of the spine following blunt trauma. Journal of Trauma and Acute Care Surgery. 1995 Dec; 39(6), 1185-1187. PMID: 7500419.

19. Ikonomidis JS, Boulanger BR, Brenneman FD. Chylothorax after blunt chest trauma: a report of 2 cases.
Canadian journal of surgery. 1997 Apr; 40(2), 135. PMID: 9126128 .

20. Kozul C, Jassal K, Judson R. Massive bilateral chylothorax post blunt trauma. Trauma case reports. 2017 Nov; 12, 63-65. PMID:29644288.

21. Brown SR, Fernandez C, Bertellotti R, Asensio JA. Blunt rupture of the thoracic duct after severe thoracic trauma. Trauma surgery \& acute care open. 2018 Jun; 3(1), e000183. PMID: 30023436.

22. Apostolakis E, Akinosoglou K, Koletsis E, Dougenis D. Traumatic chylothorax following blunt thoracic trauma: two conservatively treated cases. Journal of cardiac surgery. 2009 Mar; 24(2), 220-222. PMID: 19267837.

23. Kurklinsky AK, McEachen JC, Friese JL. Bilateral traumatic chylothorax treated by thoracic duct embolization: a rare treatment for an uncommon problem. Vascular Medicine. 2011 Aug; 16(4), 284-287. PMID: 21708873.

24. Jenkins JL, Dillard F, Shesser R. Tension chylothorax caused by occult trauma. The American journal of emergency medicine. 2004 July; 22(4), 321-323. PMID: 15258882.

25. Agrawal V, Doelken P, Sahn SA. Seat belt-induced chylothorax: a cause of idiopathic chylothorax?. Chest. 2017 Aug; 132(2), 690-692. PMID: 17699142.

26. Mohamed M, Alshenawy W, Kegarise C, Betten D. Bilateral chylothorax due to blunt trauma without radiographic evidence of traumatic injury. Clinical practice and cases in emergency medicine. 2017 Mar; 1(2), 111. PMID: 29849412.

27. Buchan KG, Hosseinpour AR, Ritchie AJ. Thoracoscopic thoracic duct ligation for traumatic chylothorax. The Annals of thoracic surgery. 2001 Sept; 72(4), 1366-1367. PMID: 11603464

28. Seitelman E, Arellano JJ, Takabe K, Barrett L, Faust G, Angus LG. Chylothorax after blunt trauma. Journal of thoracic disease. 2012 June; 4(3), 327. PMID 22754675.

29. Eren T, Demir M, Orman S, Leblebici M, Özemir ?A, Alimo?lu O. Isolated chylous injury due to blunt abdominal trauma: Report of a case and a review of the literature. Turkish journal of surgery. 2015 Jul; 33(2), 119. PMID: 28740964.

30. Dissanaike S, Griswold JA, Halldorsson A, Frezza EE. Isolated chyle duct injury in blunt trauma. The American surgeon. 2006 Feb; 72(2), 116-117. PMID: 16536238.

31. Beal AL, Gormley CM, Gordon DL, Ellis CM. Chylous ascites: a manifestation of blunt abdominal trauma in an infant. Journal of pediatric surgery. 1998 Apr; 33(4), 650-652. PMID: 9574772.

32. Tallón-Aguilar L, López-Ruiz JA, Domínguez-Sánchez C, Pareja-Ciuró F, Padillo-Ruiz J. Laparoscopic aproach in posttraumatic chylous ascites. The Annals of The Royal College of Surgeons of England. 2018 Mar; 100(3), e57-e58.PMID: 29364009. 
33. Idota N, Nakamura M, Tojo M, Ichioka H, Shintani-Ishida $\mathrm{K}$, Ikegaya $\mathrm{H}$. Infant fatality case with excessive chylous ascites. Legal Medicine. 2018 May; 32, 23-26. PMID: 29475120.

34. Maurer CA, Wildi S, Muller MF, Baer HU, Buchler MW. Blunt abdominal trauma causing chyloretroperitoneum. Journal of Trauma and Acute Care Surgery.1997 Oct; 43(4), 696-697. PMID: 9356071.

35. Calkins CM, Moore EE, Huerd S, Patten R. Isolated rupture of the cisterna chyli after blunt trauma. Journal of pediatric surgery. 2000 Apr; 35(4), 638-640. PMID: 10770405

36. Benhaim P, Strear C, Knudson MM, Neal C, Coulter K, Villarreal S. Posttraumatic chylous ascites in a child: recognition and management of an unusual condition. Journal of Trauma and Acute Care Surgery. 1995 Dec; 39(6), 11751177. PMID: 7500416.

37. Chen WL, Tsao YT. Blunt abdominal trauma: a hidden culprit. NDT plus. 2009 Apr; 2(2), 171-172. PMID: 25949320.

38. Beshay VE, Beshay JE, Rosenberg AJ. Chylous ascites in a case of child abuse. The American Journal of Gastroenterology. 2000 Sept; 95(9), 2563. PMID: 11396820.

39. Gonçalves-Matoso V, Garcia A, Grégoire A, Barghouth G. Singular and late complication of a blunt abdominal trauma: A chyloretroperitoneum. European Journal of Radiology Extra. 2006 May; 59(1), 35-37. ISSN: 1571-4675.

40. Haan JM, Montgomery S, Novosel TJ, Stein DM, Scalea TM. Chyloperitoneum after blunt abdominal injury. The American surgeon. 2007 Aug; 73(8), 811-813. PMID: 17879691 .

41. Besson R, Gottrand F, Saulnier P, Giard H, Debeugny P. Traumatic chylous ascites: conservative management. Journal of pediatric surgery. 1992 Dec; 27(12), 1543. PMID: 1469568.

42. Cerfolio RJ, Allen MS, Deschamps C, Trastek VF, Pairolero PC. Postoperative chylothorax. The Journal of thoracic and cardiovascular surgery. 1996 Nov; 112(5), 13611366. PMID: 8911335.

43. Valentine VG, Raffin TA. The management of chylothorax. Chest. 1992 Aug; 102(2), 586-591; 1992. PMID: 1643953.

44. MacNab DS, Scarlett EP. Traumatic chylothorax due to intrathoracic rupture of the thoracic duct. Canadian Medical Association Journal. 1932 Jul; 27(1), 29. PMID: 20318784.

45. Rudrappa M, Paul M. Chylothorax. StatPearls. Online Dec 2017. Available at: https://www.ncbi.nlm.nih.gov/books/NBK459206/. Accessed on May 20, 2020.

46. Majdalany BS, Murrey Jr DA, Kapoor BS, Cain TR, Ganguli S, Kent MS, Maldonado F, McBride JJ, Minocha J,
Reis SP, Lorenz JM, Kalva SP. ACR Appropriateness Criteria ${ }^{\circledR}$ Chylothorax Treatment Planning. Journal of the American College of Radiology. 2017 May; 14(5), S118S126. PMID: 28473067.

47. Pamarthi V, Pabon-Ramos WM, Marnell V, Hurwitz LM. MRI of the central lymphatic system: indications, imaging technique, and pre-procedural planning. Topics in Magnetic Resonance Imaging. 2017 Aug; 26(4), 175. PMID: 28665889.

48. Nair SK, Petko M, Hayward MP. Aetiology and management of chylothorax in adults. European journal of cardio-thoracic surgery. 2007 Aug; 32(2), 362-369. PMID: 17580118

49. Dugue L, Sauvanet A, Farges O, Goharin A, Le Mee J, Belghiti J. Output of chyle as an indicator of treatment for chylothorax complicating oesophagectomy. British journal of surgery. 1998 Aug; 85(8), 1147-1149. PMID: 9718017.

50. Matsumoto T, Yamagami T, Kato T, Hirota T, Yoshimatsu $R$, Masunami T, Nishimura $T$. The effectiveness of lymphangiography as a treatment method for various chyle leakages. The British journal of radiology. 2009 Apr; 82(976), 286-290. PMID: 19029221.

51. Alejandre-Lafont E, Krompiec C, Rau WS, Krombach GA. Effectiveness of therapeutic lymphography on lymphatic leakage. Acta Radiologica. 2011 Apr; 52(3), 305-311. PMID: 21498367.

52. Kawasaki R, Sugimoto K, Fujii M, Miyamoto N, Okada T, Yamaguchi M, Sugimura K. Therapeutic effectiveness of diagnostic lymphangiography for refractory postoperative chylothorax and chylous ascites: correlation with radiologic findings and preceding medical treatment. American Journal of Roentgenology. 2013 Sept; 201(3), 659-666. PMID: 23971461.

53. Kos $\mathrm{S}$, Haueisen $\mathrm{H}$, Lachmund $\mathrm{U}$, Roeren $\mathrm{T}$. Lymphangiography: forgotten tool or rising star in the diagnosis and therapy of postoperative lymphatic vessel leakage. Cardiovascular and interventional radiology. 2007 Oct; 30(5), 968-973. PMID: 17508245.

54. Guermazi A, Brice P, Hennequin C, Sarfati E. Lymphography: an old technique retains its usefulness. Radiographics. 2003 Dec; 23(6), 1541-1558. PMID: 14615563.

55. Itkin M, Kucharczuk JC, Kwak A, Trerotola SO, Kaiser LR. Nonoperative thoracic duct embolization for traumatic thoracic duct leak: experience in 109 patients. The Journal of thoracic and cardiovascular surgery. 2010 Mar; 139(3), 584590. PMID:20042200.

56. Laslett D, Trerotola SO, Itkin M. Delayed complications following technically successful thoracic duct embolization. Journal of Vascular and Interventional Radiology. 2012 Jan; 23(1), 76-79. PMID: 22115569.

57. Meguid RA. Chylothorax: surgical ligation of the thoracic duct through thoracotomy. Operative Techniques in Thoracic 
and Cardiovascular Surgery. 2016 Jun; 21(2), 139-151. ISSN: 1522-2942.

58. Inan N, Arslan A, Akansel G, Arslan Z, Eleman L, Demirci A. Diffusion-weighted MRI in the characterization of pleural effusions. Diagnostic and Interventional Radiology. 2009 Mar; 15(1), 13. PMID: 19263368.

59. Light RW, Macgregor MI, Luchsinger PC, Ball WC. Pleural effusions: the diagnostic separation of transudates and exudates. Annals of internal medicine. 1972 Oct; 77(4), 507513. PMID: 4642731.

60. Weese WC, Shindler ER, Smith IM, Rabinovich S. Empyema of the thorax then and now: a study of 122 cases over four decades. Archives of internal medicine. 1973 Apr; 131(4), 516-520.PMID: 4699956.

61. Kraus GJ. The split pleura sign. Radiology. 2007 Apr; 243(1), 297-298. PMID: 17392263.

62. Kearney SE, Davies CWH, Davies RJO, Gleeson FV. Computed tomography and ultrasound in parapneumonic effusions and empyema. Clinical radiology. $2000 \mathrm{Jul}$; 55(7), 542-547. PMID: 10924379.

63. Burrill J, Williams CJ, Bain G, Conder G, Hine AL, Misra, RR. Tuberculosis: a radiologic review. Radiographics. 2007 Oct; 27(5), 1255-1273. PMID: 17848689.

64. Restrepo CS, Katre R, Mumbower A. Imaging manifestations of thoracic tuberculosis. Radiologic Clinics. 2016 May; 54(3), 453-473. PMID: 27153783.

65. Woodring JH, Vandiviere HM, Fried AM, Dillon ML, Williams TD, Melvin IG. Update: the radiographic features of pulmonary tuberculosis. American journal of roentgenology. 1986 Mar; 146(3), 497-506. PMID: 3484866.

66. Bhalla AS, Goyal A, Guleria R, Gupta AK. Chest tuberculosis: Radiological review and imaging recommendations. The Indian journal of radiology \& imaging. 2015 Sept; 25(3), 213. PMID: 26288514.

67. Dreizin D, Munera F. Multidetector CT for penetrating torso trauma: state of the art. Radiology. 2015 Nov; 77(2), 338-355. PMID: 26492022.

68. Talbot BS, Gange Jr CP, Chaturvedi A, Klionsky N, Hobbs SK, Chaturvedi A. Traumatic rib injury: patterns, imaging pitfalls, complications, and treatment. Radiographics. 2017 Apr; 37(2), 628-651. PMID: 28186860.

69. Wolverson MK, Crepps LF, Sundaram M, Heiberg E, Vas WG, Shields JB. Hyperdensity of recent hemorrhage at body computed tomography: incidence and morphologic variation. Radiology. 1983 Sept; 148(3), 779-784. PMID: 6878700.

70. Ali HA, Lippmann M, Mundathaje U, Khaleeq G. Spontaneous hemothorax: a comprehensive review. Chest. 2008 Nov; 134(5), 1056-1065. PMID: 18988781. 


\section{FIGURES}

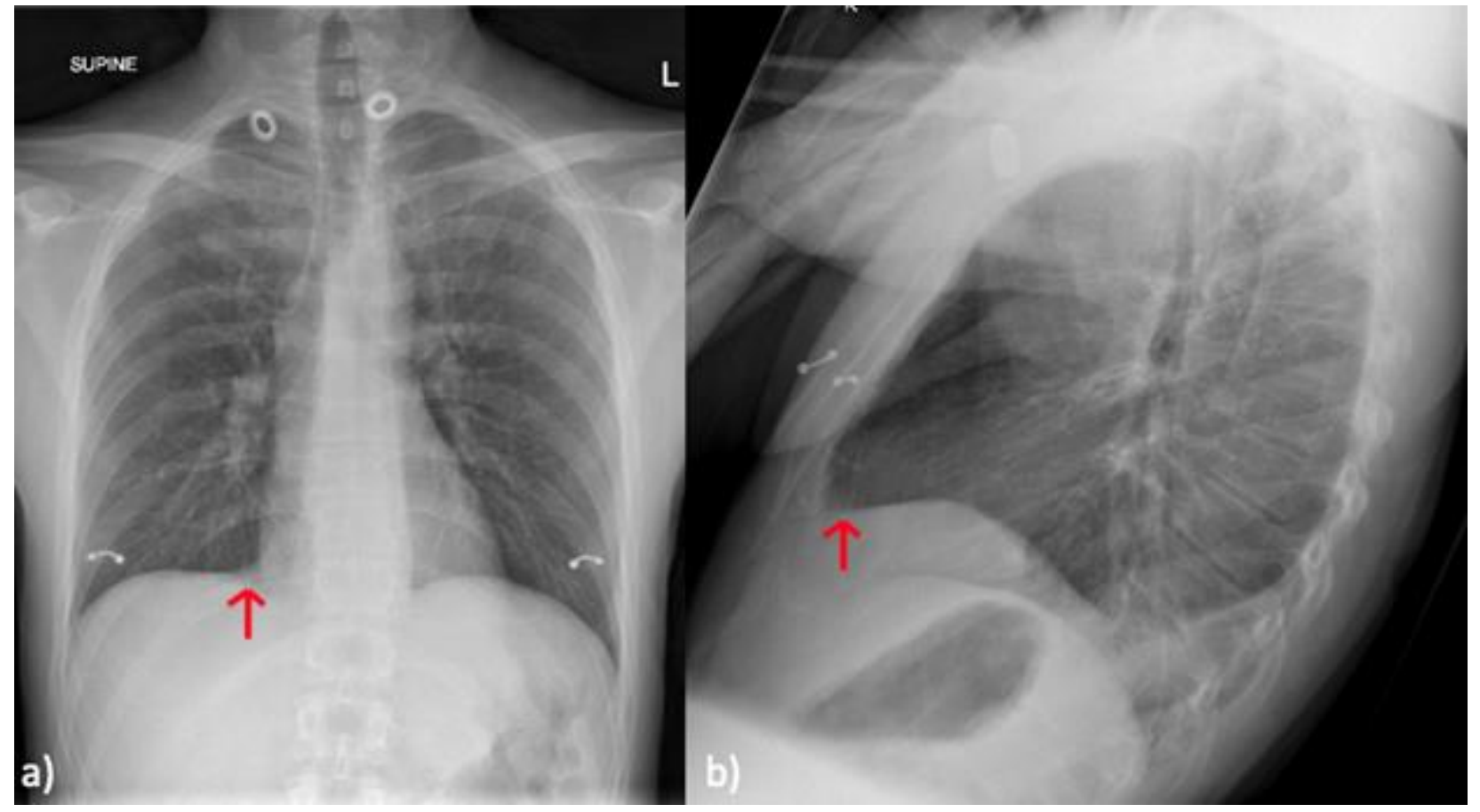

Figure 1: Chest radiographs of a 29-year-old male with bilateral chylothorax.

FINDINGS: a) Posterior-anterior view and b) lateral view of the chest reveals bilateral blunting of the costophrenic and costocardiac angles suggestive of a small bilateral pleural effusion.

TECHNIQUE: Plain film of the chest taken at $120 \mathrm{kVp}$.

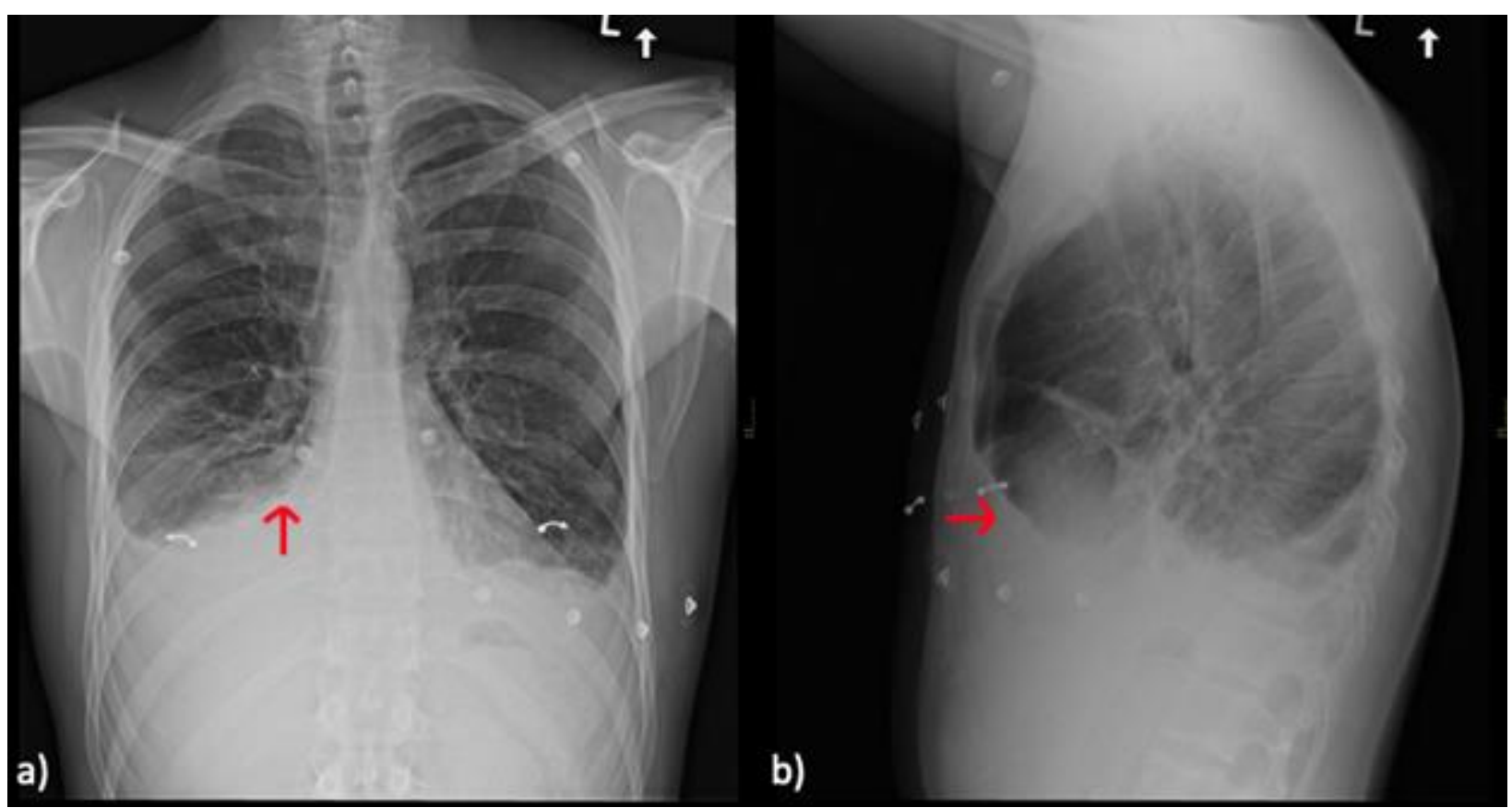

Figure 2: Chest X-ray of a 29-year-old male with bilateral chylothorax.

FINDINGS: a) Posterior-anterior view and b) lateral view of the chest reveals enlarging bilateral pleural effusions now moderate in volume on the right and small to moderate in volume on the left.

TECHNIQUE: Plain film of the chest taken at $120 \mathrm{kVp}$. 


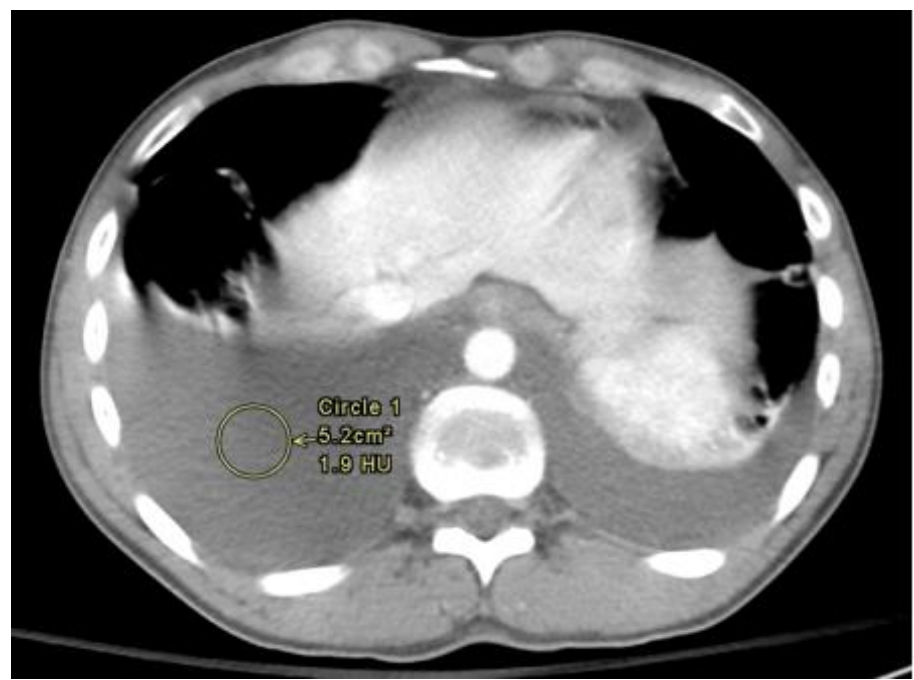

Figure 3 (left): Initial CT of a 29-year-old male with bilateral chylothorax.

FINDINGS: Large right and a moderate left pleural effusion with low attenuation.

TECHNIQUE: Contrast enhanced axial CT thorax with multiplanar reformats. A CT GE LightSpeed VCT was used. Images were taken at $120 \mathrm{kVp}, \mathrm{mA}$ of 225 , with $5 \mathrm{~mm}$ slice thickness. $120 \mathrm{~mL}$ of Omnipaque 350 were provided.

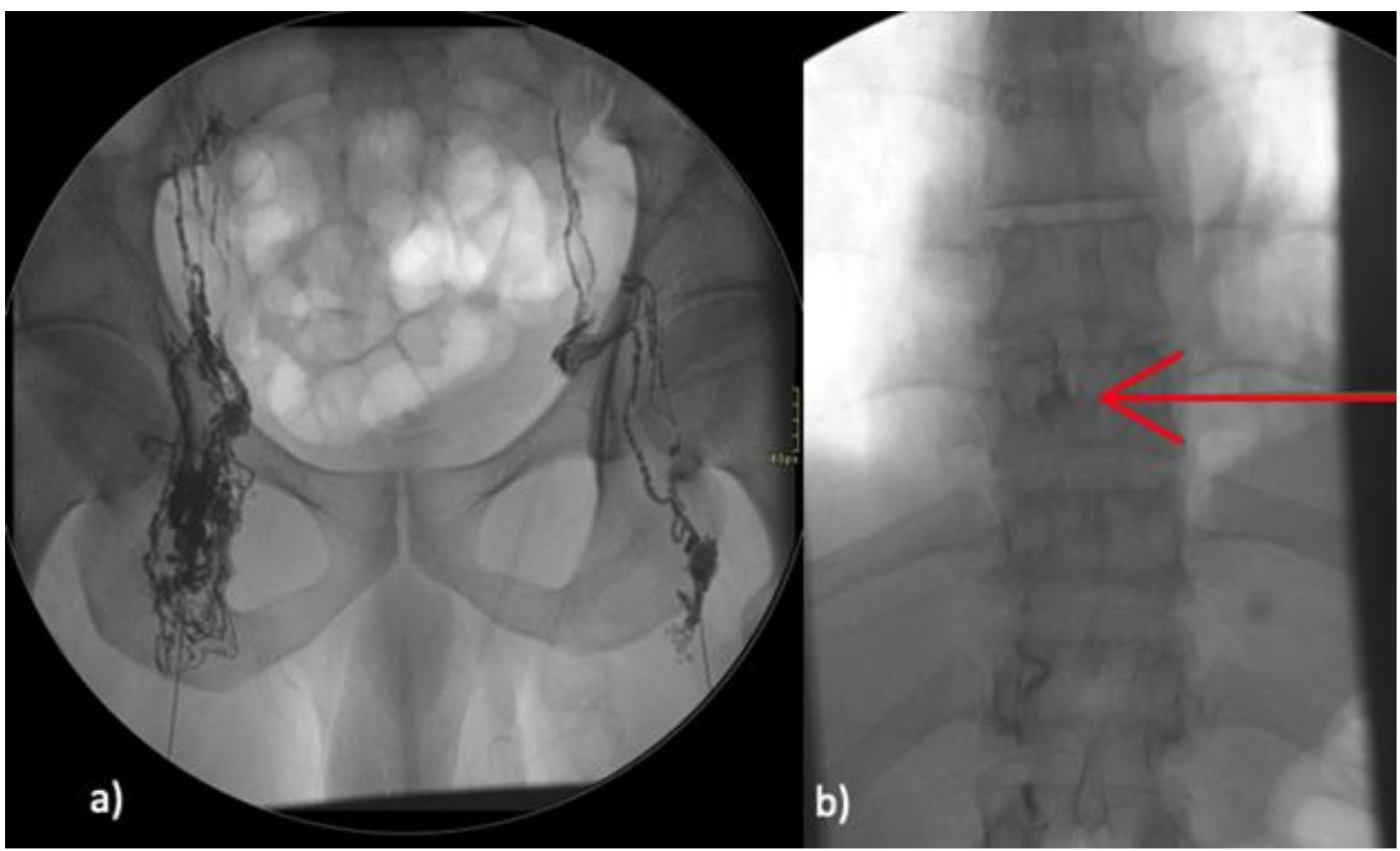

Figure 4: Bilateral pelvic lymphangiogram on a 29-year-old male presenting with bilateral chylothorax.

FINDINGS: a) Following infusion of Lipiodol excellent uptake can be seen in the pelvic lymphatic chain bilaterally. b) An amorphous pool of Lipiodol begins to form over the 10th thoracic vertebral level as indicated by the yellow arrow.

TECHNIQUE: Bilateral inguinal lymph nodes were targeted with a 22-gauge needle under direct ultrasound guidance and $30 \mathrm{~mL}$ of Lipiodol was slowly infused into the lymphatic system. Intermittent fluoroscopy was subsequently performed. 


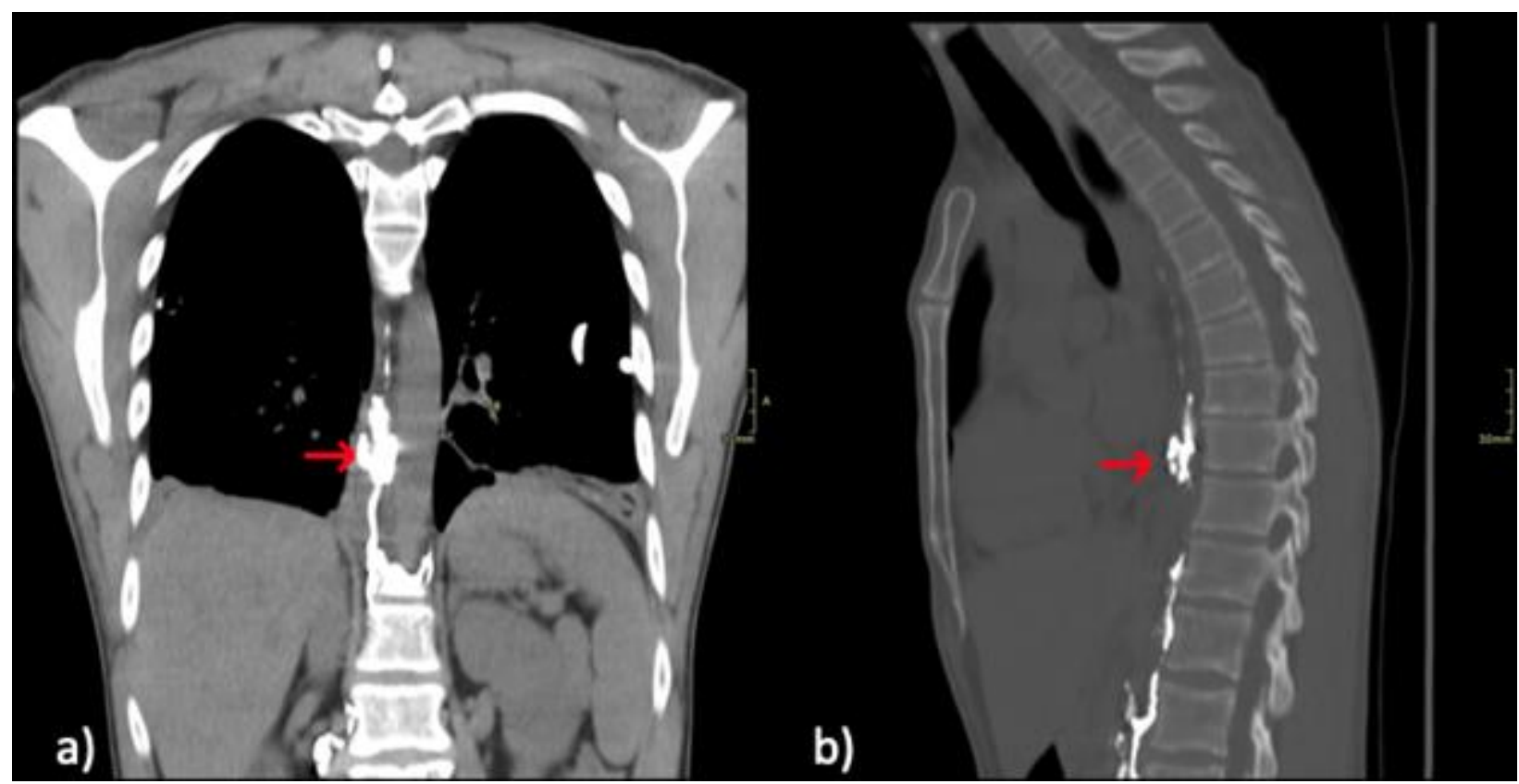

Figure 5: Non-contrast CT following percutaneous lymphangiogram on 29-year-old male presenting with bilateral chylothorax.

FINDINGS: Follow up CT confirmed the presence of an amorphic accumulation of Lipiodol to the right of the thoracic aorta centered at the 10th thoracic vertebral body as indicated by the red arrow in a) the coronal plane and b) the sagittal plane. The intact thoracic duct can be seen below this and the diminished caliber thoracic duct is shown above the disruption/transection

TECHNIQUE: Non-contrast axial CT with multiplanar reformats. A CT GE LightSpeed VCT was used. Images were taken at $120 \mathrm{kVp}, 210 \mathrm{~mA}$, with $3 \mathrm{~mm}$ slice thickness.

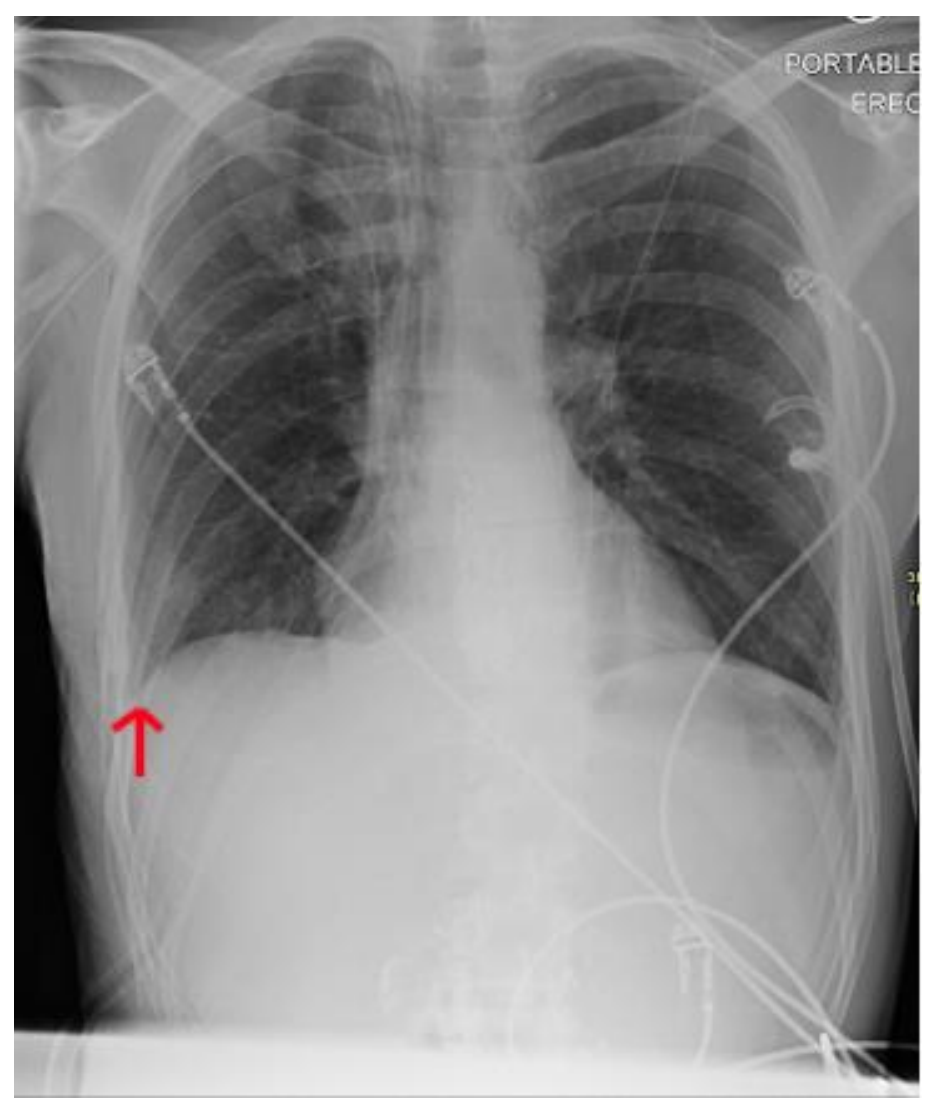

Figure 6 (left): Postoperative portable chest radiograph following thoracic duct ligation and talc pleurodesis on a 29year-old male presenting with bilateral chylothorax.

FINDINGS: First postoperative portable chest radiograph. There are bilateral chest tubes and a pigtail pleural catheter on the left side. There is mild blunting of the costophrenic recess bilaterally, in keeping with small pleural effusions.

TECHNIQUE: Plain film of the chest taken at $101 \mathrm{kVp}$. 


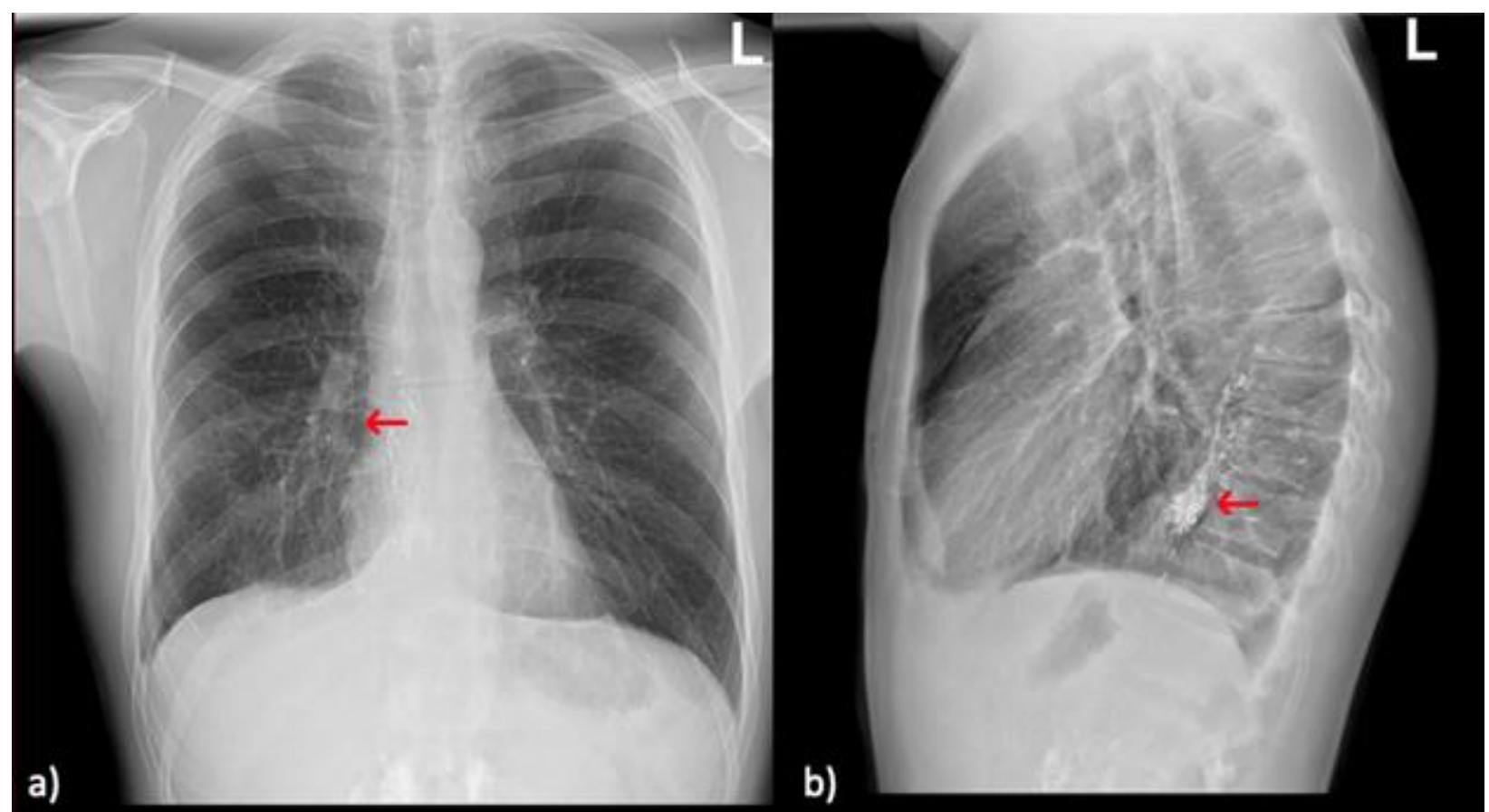

Figure 7: Chest radiographs of 29-year-old male 6 weeks post thoracic duct ligation with talc pleurodesis for bilateral chylothorax.

FINDINGS: Irregular dense material in the middle/posterior mediastinum and epigastric region represents resolving retained lymphangiogram contrast. Trace residual right pleural effusion.

TECHNIQUE: Plain film of the chest taken at $120 \mathrm{kVp}$.

\begin{tabular}{|l|l|}
\hline Etiology & $\begin{array}{l}\text { Increased intrathoracic pressure and/or hyperextension of the spine leading to damage of the thoracic } \\
\text { duct }\end{array}$ \\
\hline Incidence & Insufficient evidence to determine incidence \\
\hline Gender Ratio & No predilection \\
\hline Age predilection & No predilection \\
\hline Risk Factors & Prior trauma to thoracic duct, infection, congenital anomaly, and malignancy \\
\hline Treatments & $\begin{array}{l}\text { Conservative management: NPO status, total parenteral nutrition, octreotide, thoracentesis } \\
\text { Definitive management: lymphangiogram, thoracic duct embolization/disruption, thoracic duct } \\
\text { ligation } \pm \text { pleurodesis }\end{array}$ \\
\hline Prognosis & $\begin{array}{l}\text { If untreated up to 50\% mortality rate. Thoracic duct ligation has a 90\% success rate with minimal } \\
\text { long-term sequelae. }\end{array}$ \\
\hline Findings on Imaging & $\begin{array}{l}\text { Presence of pleural effusion: Homogeneous opacities causing blunting of the costophrenic and } \\
\text { costocardiac angles. }\end{array}$ \\
\hline
\end{tabular}

Table 1: Summary table of isolated thoracic duct injury and chylothorax due to blunt trauma. 


\begin{tabular}{|c|c|c|c|c|}
\hline & $\mathbf{U S}$ & X-Ray & CT & $\begin{array}{l}\text { Laboratory } \\
\text { Analysis }\end{array}$ \\
\hline Chylothorax & $\begin{array}{l}\text { - Homogeneous } \\
\text { anechoic collection } \\
\text { - No areas of } \\
\text { loculation or } \\
\text { separation }\end{array}$ & $\begin{array}{l}\text { - Blunting of the costophrenic } \\
\text { and costocardiac angles } \\
\text { - Homogeneous density }\end{array}$ & $\begin{array}{l}\text { - Low attenuation } \\
\text { compared to other causes } \\
\text { of pleural effusion } \\
\text { - Evidence of damage to } \\
\text { thoracic duct }\end{array}$ & $\begin{array}{l}\text { - Triglyceride } \\
>1.24 \mathrm{mmol} / \mathrm{L} \\
\text { - Cholesterol } \\
\text { - }<5.18 \mathrm{mmol} / \mathrm{L}\end{array}$ \\
\hline $\begin{array}{l}\text { Transudative } \\
\text { Effusion }\end{array}$ & $\begin{array}{l}\text { Anechoic fluid } \\
\text { collection. }\end{array}$ & $\begin{array}{l}\text { Bilateral blunting of the } \\
\text { costophrenic and costocardiac } \\
\text { angles }\end{array}$ & $\begin{array}{l}\text { Homogeneous, fluid } \\
\text { attenuation collection }\end{array}$ & $\begin{array}{l}\text { Negative Light's } \\
\text { Criteria }\end{array}$ \\
\hline $\begin{array}{l}\text { Parapneumonic } \\
\text { Pleural Effusion/ } \\
\text { Empyema }\end{array}$ & $\begin{array}{l}\text { - } \pm \text { Evidence of } \\
\text { consolidation } \\
\text { - Adhesions may be } \\
\text { detectable on US if } \\
\text { empyema develops }\end{array}$ & $\begin{array}{l}\text { - Presence of lobar, bronchial, } \\
\text { or interstitial pneumonia } \\
\text { - Parapneumonic effusion will } \\
\text { localize to the dependent } \\
\text { areas of the lungs } \\
\text { - Empyema will initially be } \\
\text { freely layering but may } \\
\text { become loculated }\end{array}$ & $\begin{array}{l}\text { - Presence of split pleural } \\
\text { sign due to elevated } \\
\text { enhancement of pleural } \\
\text { lining } \\
\text { - Pleural thickening }\end{array}$ & $\begin{array}{l}\text { Empyema will } \\
\text { have a positive } \\
\text { culture }\end{array}$ \\
\hline Tuberculosis & +Septated effusions & $\begin{array}{l}\text { - Focal infiltration of upper or } \\
\text { lower lobes } \\
\text { - Cavitation and inflammation } \\
\text { - Enlarged hilar and } \\
\text { mediastinal lymph nodes }\end{array}$ & $\begin{array}{l}\text { - Variable appearance } \\
\text { - Pleural TB may show } \\
\text { rim enhancing collection, } \\
\text { loculations/septations }\end{array}$ & $\begin{array}{l}\text { - Positive acid- } \\
\text { fast bacilli stain } \\
\text { - Positive culture } \\
\text { of } \\
\text { Mycobacterium } \\
\text { tuberculosis }\end{array}$ \\
\hline $\begin{array}{l}\text { Malignant } \\
\text { Pleural Effusion }\end{array}$ & $\begin{array}{l}\text { May demonstrate a } \\
\text { lesion in the pleural } \\
\text { fluid, may be } \\
\text { heterogeneous } \\
\text { echogenicity }\end{array}$ & $\begin{array}{l}\text { Potential indicators for } \\
\text { malignancy such as pulmonary } \\
\text { masses, nodules, atelectasis } \\
\text { from bronchial obstruction or } \\
\text { lymphadenopathy }\end{array}$ & $\begin{array}{l}\text { Irregularities, nodules or } \\
\text { thickening of the pleura } \\
\text { present }\end{array}$ & Positive cytology \\
\hline Hemothorax & $\begin{array}{l}\text { Homogenous } \\
\text { echogenicity pleural } \\
\text { collection }\end{array}$ & $\begin{array}{l}\text { - Hemothoraces greater than } \\
500 \mathrm{~mL} \text { are detectable on } \\
\text { upright chest X-ray } \\
\text { - Blunting of the costophrenic } \\
\text { and costocardiac angles }\end{array}$ & $\begin{array}{l}\text { - Can detect smaller } \\
\text { hemothoraces than X-ray } \\
\text { - Fresh blood has } \\
\text { attenuation of } \\
\text { approximately } 35 \mathrm{HU} \\
\text { while clotted blood may } \\
\text { have an attenuation of } \\
\text { approximately } 70 \mathrm{HU}\end{array}$ & $\begin{array}{l}\text { Ratio of pleural } \\
\text { fluid/blood }>0.25 \\
-0.5\end{array}$ \\
\hline
\end{tabular}

Table 2: Differential diagnosis table for chylothorax.

\section{ABBREVIATIONS}

$\mathrm{CT}=$ Computed tomography

$\mathrm{HU}=$ Hounsfield Unit

MRI = Magnetic resonance imaging

$\mathrm{NPO}=$ Nil per os

$\mathrm{TB}=$ Tuberculosis

TDE $=$ Thoracic duct embolization

TDL $=$ Thoracic duct ligation

US = Ultrasound

\section{Online access}

This publication is online available at:

www.radiologycases.com/index.php/radiologycases/article/view/3977

\section{Peer discussion}

Discuss this manuscript in our protected discussion forum at: www.radiolopolis.com/forums/JRCR

\section{Interactivity}

\section{KEYWORDS}

lymphangiogram; thoracic duct; chylothorax; trauma; lymphatics

\section{ACKNOWLEDGEMENTS}

Dr. Dalilah Fortin and Dr. Richard Malthaner, the thoracic surgeons.

This publication is available as an interactive article with scroll, window/level, magnify and more features.

Available online at www.RadiologyCases.com

\section{Published by EduRad}

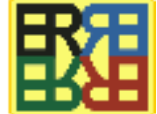

www.EduRad.org 